\title{
21. LIPID GEOCHEMISTRY OF SEDIMENTS FROM SITE 462 IN THE NAURU BASIN 1,2
}

\author{
Bernd R. T. Simoneit, Institute of Geophysics and Planetary Physics, University of California, \\ Los Angeles, California
}

\begin{abstract}
The lipids of a Pliocene and a Cretaceous sample from Site 462 were analyzed to assess their source and diagenetic history. Judging from the distributions of the $n$-alkanes, $n$-fatty acids, $n$-alkylcyclohexanes and molecular markers, they are autochthonous, of marine origin, and deposited under oxic paleoenvironmental conditions of sedimentation. The stereochemistry of the various molecular markers (e.g., triterpanes and steranes) of the Pliocene sample indicates that the lipids are geologically mature. This supports the hypothesis of sediment recycling from older formations by turbidite redistribution into the Nauru Basin.
\end{abstract}

\section{INTRODUCTION}

The Nauru Basin, in the west-central Pacific, is remote from terrigenous influences, but receives much of its sedimentary detritus by turbidite deposition (Larson et al., 1978). It is of interest to determine the nature and source of the organic matter brought into this pelagic basin.

Samples 462-3-4, 100-150 cm and 462-59-1, 100-125 $\mathrm{cm}$ were analyzed. The upper sample consists of calcareous and radiolarian ooze of Pliocene age, derived from 25.25 meters sub-bottom, and the lower sample is a zeolitic claystone of Campanian to Santonian age, from 550.6 meters sub-bottom. Site 462 is in the central Nauru Basin, at $07^{\circ} 14.25^{\prime} \mathrm{N}, 165^{\circ} 01.83^{\prime} \mathrm{E}$, in 5189 meters of water.

\section{EXPERIMENTAL PROCEDURES}

The core samples were freeze-dried, then extracted with chloroform and methanol $(1: 1)$, using ultrasonication. The extracts were derivatized and separated by thin-layer chromatography, as described by Simoneit (1979). The fractions were analyzed by gas chromatography and by gas chromatography/mass spectrometry, using the conditions described by Simoneit (1979).

\section{RESULTS}

The results of the carbon and lipid analyses are summarized in Table 1. The organic-carbon content of the Pliocene sample is low, and the lipid yield, especially of the hydrocarbons, is high. The total lipid and organiccarbon content of the Cretaceous sample is very low.

The distribution diagrams for the various homologous series are shown in Figure 1 . The $n$-alkanes of sample 462-3-4, 100-150 cm (Fig. 1A) exhibit an essentially unimodal distribution, with a maximum at $\mathrm{C}_{22}$, and only a minor odd-to-even carbon number predominance. The homologs $<\mathrm{C}_{25}$ are probably indicative of an origin from both degraded algae and bacteria (Simoneit, 1979). Only traces of $n$-alkanes $\left(>n-C_{27}\right.$, odd-

\footnotetext{
1 Initial Reports of the Deep Sea Drilling Project, Volume 61 .

${ }^{2}$ Contribution No. 2087, Institute of Geophysics and Planetary Physics, University of California at Los Angeles.
}

carbon-number predominance) derived from higherplant wax are present (Simoneit, 1978). The pristane-tophytane ratio is 0.95 , which coupled with the lithologic data indicates a low-oxygen sedimentary paleoenvironment, but not completely anoxic (Didyk et al., 1978). The $n$-fatty acids of this sample (Fig. 1B) range from $\mathrm{C}_{10}$ to $\mathrm{C}_{32}$, with a strong even-to-odd carbon-number predominance (CPI $>7.6$ ), and maxima at $\mathrm{C}_{16}$ (major) and $\mathrm{C}_{28}$ (minor). The homologs $<\mathrm{C}_{20}$ indicate a primarily microbial origin, and those $>\mathrm{C}_{22}$ are derived from vascular-plant wax (Simoneit, 1978, 1979). A trace of dehydroabietic acid is found in the acid fraction, indicating a very minor influx of detritus from resinous higher plants (Simoneit, 1977). Perylene was not detectable.

Because of the low extract yield from Sample $462-59-1,100-125 \mathrm{~cm}$, only the total fraction could be analyzed. The dominant homologous compounds in the lipids were $n$-alkanes and $n$-fatty acids (Fig. 1C,D). The $n$-alkanes exhibit a trimodal distribution, ranging from $\mathrm{C}_{11}$ to $\mathrm{C}_{31}$, with a low CPI of 1.2 and maxima at $\mathrm{C}_{17}$, $\mathrm{C}_{19}$, and $\mathrm{C}_{22}$. This distribution is characteristic of degraded autochthonous microbial lipids of a marine origin. Perylene was not detectable. The $n$-fatty acids exhibit a bimodal distribution, ranging from $\mathrm{C}_{10}$ to $\mathrm{C}_{26}$, with a CPI of 6.2 and maxima at $C_{16}$ and $C_{22}$. This distribution is also characteristic of primarily autochthonous microbial detritus of a marine origin. Dehydroabietic acid was not detectable.

Various molecular markers that could be correlated with biogenic sources were determined. Sesquiterpenoids and diterpenoids were not detectable in both samples. The following markers could be confirmed in sample $462-3-4,100-150 \mathrm{~cm}$ only. A series of $n$-alkylcyclohexanes, ranging from $\mathrm{C}_{14}$ to $\mathrm{C}_{27}$, with a maximum at $\mathrm{C}_{21}$ was present (Fig. 1E). These compounds are microbial lipid residues (Simoneit, 1978, 1979). Minor amounts of extended diterpanes (I), ranging from $\mathrm{C}_{19}$ to $\mathrm{C}_{26}$ are present (Fig. 1F), also indicating autochthonous material. The steranes were present as trace components only and exhibited complex isomeric distributions where the $5 \alpha(\mathrm{H})$-steranes (II) and the $5 \alpha(\mathrm{H}), 14 \beta(\mathrm{H})$-steranes 
Table 1. Results of carbon and lipid analyses.

\begin{tabular}{|c|c|c|c|c|c|c|c|c|c|c|c|}
\hline \multirow[b]{2}{*}{ Sample } & \multicolumn{2}{|c|}{ Carbon $^{a}$} & \multirow[b]{2}{*}{$\underset{(\%)}{\mathrm{CaCO}_{3}{ }^{\mathrm{a}}}$} & \multirow{2}{*}{$\begin{array}{l}\text { Total } \\
\text { Lipids } \\
(\mu \mathrm{g} / \mathrm{g})^{\mathrm{b}}\end{array}$} & \multicolumn{3}{|c|}{$n$-alkanes } & \multirow[b]{2}{*}{$\mathrm{Pr} / \mathrm{Ph}^{e}$} & \\
\hline & $\begin{array}{l}\text { Total } \\
(\%)\end{array}$ & $\underset{\left(\%_{0)}\right.}{\text { Organic }}$ & & & $\mu \mathrm{g} / \mathrm{g}^{\mathrm{b}}$ & $\frac{n \text {-alkan }}{\mathrm{CPI}^{\mathrm{C}}}$ & $\frac{s}{\text { Max. }^{d}}$ & & $\overline{\mu g / g^{b}}$ & $\frac{\text { fatty ac }}{\mathrm{CPI}^{\mathrm{C}}}$ & $\operatorname{Max}^{\mathrm{d}}$ \\
\hline $462-3-4,100-150 \mathrm{~cm}$ & 0.1 & 0.1 & 0 & 1400 & 460 & 1.2 & $17, \underline{22}$ & 0.95 & 130 & 7.6 & 16,28 \\
\hline $462-59-1,100-125 \mathrm{~cm}$ & 0.0 & 0.0 & 0 & 15 & ${ }^{400}$ & 1.2 & $17,19,22$ & 1.7 & 3 & 6.2 & $\frac{10,20}{16,22}$ \\
\hline
\end{tabular}

a Data provided by G. Bode, Deep Sea Drilling Project.

Based on dry sediment weight.

c Carbon-preference index, summed from $C_{10}-C_{35}$, odd-to-even for $n$-alkanes, even-to-odd for $n$-fatty acids.

d The dominant homolog is underscored.

e Pristane-to-phytane ratio.
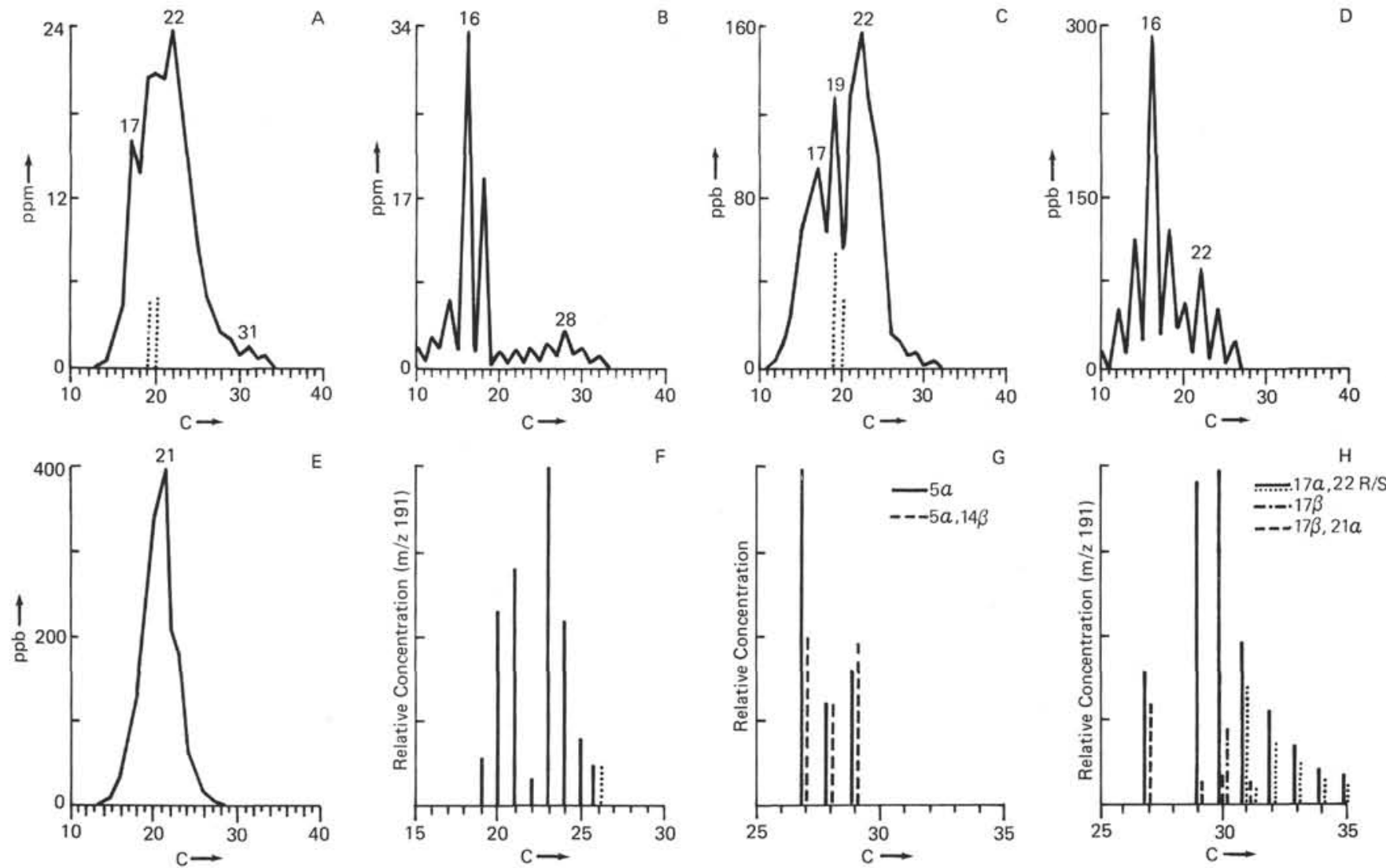

Figure 1. Distribution diagrams for $n$-alkanes, $n$-fatty acids and molecular markers in the lipids of the samples from Site 462. Sample 462-3-4, 100-150 cm: A. $n$-alkanes. B. $n$-fatty acids. E. $n$-alkylcyclohexanes. F. Extended diterpanes (I). G. Steranes. H. Triterpanes. Sample 462-59-1, $100-125 \mathrm{~cm}$ : C. $n$-alkanes. D. $n$-fatty acids.

(III) were dominant (Fig. 1G). The $5 \beta(\mathrm{H})$ stereomers were not detectable. The distribution with cholestane as the dominant homolog indicates autochthonous marine material (Gaskell, 1974; Rubinstein, 1973).

Triterpenoids are present primarily as the $17 \alpha(\mathrm{H})$ hopane (IV) series, with lesser amounts of the moretanes (V) and trace of $17 \beta(\mathrm{H})$-hopanes (Fig. 1H). The homologs range from $\mathrm{C}_{27}, \mathrm{C}_{29}$ to $\mathrm{C}_{35}$, where the compounds $>\mathrm{C}_{31}$ are resolved into $R$ and $S$ diastereomers (VI) at C-22 in the approximate ratio of $S / R=$ 1.4. The source of these triterpenoids is marine microbial detritus. The presence of the $17 \alpha(\mathrm{H})$ stereomers and an almost equal proportion of the $22 S$ and $R$ isomers (Dastillung and Albrecht, 1976), coupled with the steranes and other markers, indicate that the lipids of this shallow sample are old (mature), and not syngenetic. They probably were introduced from geologically older sediments by erosion and redeposition.

\section{CONCLUSION}

The lipids of both samples from the Nauru Basin are primarily autochthonous and marine, with only traces of terrestrial higher-plant wax residues.

The molecular markers in the lipids of Sample 462$3-4,100-150 \mathrm{~cm}$ are diagenetically older than the sediment, i.e., they are quite mature. This indicates and supports the fact of turbidite deposition, in which older material was brought to this pelagic basin. 


\section{ACKNOWLEDGMENTS}

I thank D. Blumfield for technical assistance, E. Ruth for GC/MS data acquisition, and M. I. Venkatesan and M. A. Mazurek for review of this note.

\section{REFERENCES}

Dastillung, M., and Albrecht, P., 1976. Molecular test for oil pollution in surface sediments. Mar. Poll. Bull., 7:13-15.

Didyk, B. M., Simoneit, B. R. T., Brassell, S. C., et al., 1978. Geochemical indicators of palaeoenvironmental conditions of sedimentation. Nature, 272:216-222.

Gaskell, S. J., 1974. The environmental geochemistry of sterols [Ph.D. dissert]. University of Bristol, England.

Larson, R. L., Schlanger, S., et al., 1978. Volcanic complex found in the west-central Pacific. Geotimes, 23:21-24.

Rubinstein, I., 1973. A study of marine sterols [Ph.D. dissert]. University of Liverpool, England.

Simoneit, B. R. T., 1977. Diterpenoid compounds and other lipids in deep-sea sediments and their geochemical significance. Geochim. Cosmochim. Acta, 41:463-476.

1978. The organic chemistry of marine sediments. In Riley, J. P., and Chester, R. (Eds.), Chemical Oceanography, 2nd ed. (Vol. 7): New York (Academic Press), pp. 233-311.

1979. Lipid geochemistry of Cretaceous black shales from the Bay of Biscay, Site 402, and of Eocene mudstone from the Rockall Plateau, Site 402. In Montadert, L., Roberts, D. G., et al., Init. Repts. DSDP, 48: Washington (U.S. Govt. Printing Office), 935-941.

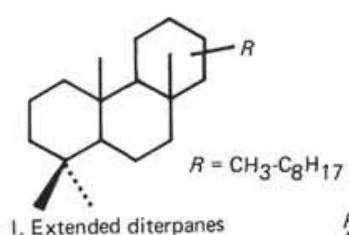

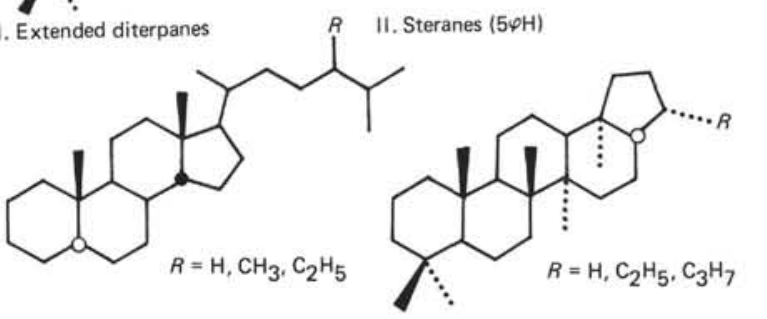

III. Steranes $\langle 5 a, 14 \beta \mathrm{H}$

IV. $17 a(\mathrm{H})$-Hopanes

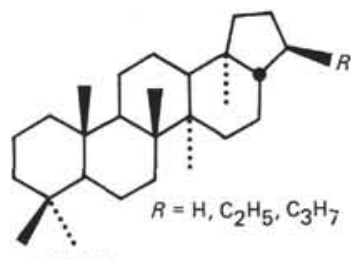

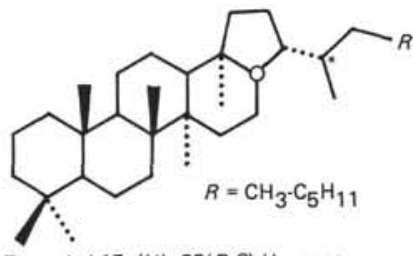

V. $17 \beta(\mathrm{H}) \cdot$-Moretanes

VI. Extended $17 a(H), 22(R, S) \cdot$ Hopanes 